\title{
Potential field interpretation of the Baie Verte Peninsula, Newfoundland, utilizing constraints from Lithoprobe East Seismic line 89-13
}

\author{
Hugh G. Miller and R. Wiseman \\ Department of Earth Sciences, Memorial University of Newfoundland, \\ St. John's, Newfoundland AIB 3X5, Canada \\ Date Received October 6, 1993 \\ Date Accepted November 9, 1993
}

\begin{abstract}
An understanding of the geological setting of the Baie Verte Peninsula of Newfoundland is central to many interpretations of the Canadian Appalachians. In this paper we present an interpretation of the magnetic and gravity data for the area utilizing constraints from Lithoprobe Vibroseis line 89-13 which traverses the peninsula.

The potential field data were processed using a number of techniques to provide shaded relief and other maps providing information on the depth of the sources. Density and magnetic susceptibility data were used in modelling the gravity and magnetic responses for two profiles, one the Lithoprobe line 89-13, and the other a profile farther north. The reflection seismic section was used to constrain the modelling.

The Baie Verte Line is interpreted to be confined to the upper few kilometers of the crust. A prominent feature on the seismic section, and its corresponding step on the gravity and magnetic profiles, is interpreted to be the subsurface westward edge of a wedge of intact ophiolitic crust found on the eastern part of the peninsula. This feature is traced away from the seismic line by utilizing its potential field signature.

The modelling and processing suggest that the potential field signatures can all be explained by sources in the upper 10 $\mathrm{km}$ of the crust, a conclusion consistent with earlier interpretations which were based on potential field data alone.
\end{abstract}

La compréhension du contexte géologique de la péninsule de Baie Verte de Terre-neuve est un élément crucial pour plusieurs interprétations des Appalaches canadiennes. Dans cet article, nous présentons une interprétation des données magnétiques et gravimétriques pour la région en utilisant des éléments provenant de la ligne de Vibroseis de Lithoprobe 8913 qui traverse la péninsule.

Les données du champ potentiel furent traitées en utilisant un certain nombre de techniques pour créer des reliefs ombragés et d'autres cartes fournissant de l'information sur la profondeur des sources. Les données de densité et de susceptibilité magnétique furent utilisées pour la modélisation des réponses gravimétriques et magnétiques pour deux sections, l'une étant la ligne Lithoprobe 89-13, et l'autre étant située plus au nord. La coupe de sismique réflexion fut utilisée pour préciser le modèle.

La ligne de Baie Verte est interprétée comme étant restreinte aux quelques kilomètres supérieurs de la croûte. Un élément important de la coupe sismique, et une variation y correspondant sur les profils gravimétriques et magnétiques, est interprété comme étant la marge occidentale enfouie d'un biseau de croûte ophiolitique intacte qui se retrouve sur la partie est de la péninsule. Cet élément est suivi à distance du profil sismique en utilisant sa signature en champ potentiel.

La modélisation et le traitement suggèrent que les signatures en champ potentiel peuvent toutes être expliquées par des sources dans les $10 \mathrm{~km}$ supérieurs de la croûte, une conclusion en accord avec les interprétations antérieures qui étaient fondées uniquement sur les données du champ potentiel.

\section{INTRODUCTION}

[Traduit par la rédaction]

The Baie Verte Peninsula, sometimes referred to as the Burlington Peninsula in older literature, is a pivotal location in Newfoundland, and indeed, Canadian Appalachian geology, for it is here that the boundary between the autochthonous Humber Zone and accreted suspect terranes to the east is exposed. The line of demarcation, the Baie Verte Line, is considered a fundamental feature of Appalachian geology and its correlatives have been identified elsewhere in the system (Williams, 1979; Williams and Hatcher, 1983). However, the nature of this feature has been questioned as more geophysical data became available (Miller and Deutsch, 1976; Miller, 1990; Keen et al., 1987; Quinlan et al., 1992).

Lithoprobe Publication No. 507
The objective of the present paper is to re-examine the potential field data for the area and to link its interpretation with the results of the Lithoprobe East deep seismic reflection studies, specifically line LE89-13 which provides a transect across the peninsula (Fig. 1).

\section{General Geology}

The Lithoprobe East Burlington transect (LE89-13) traverses the Baie Verte Peninsula from Western Arm to Burlington (Fig. 1). The transect crosses the Baie Verte Line, which is considered to be the surface boundary between the Humber Zone to the west and the Dunnage Zone to the east (St. Julien et al., 1976; Williams and St. Julien, 1978; Williams, 


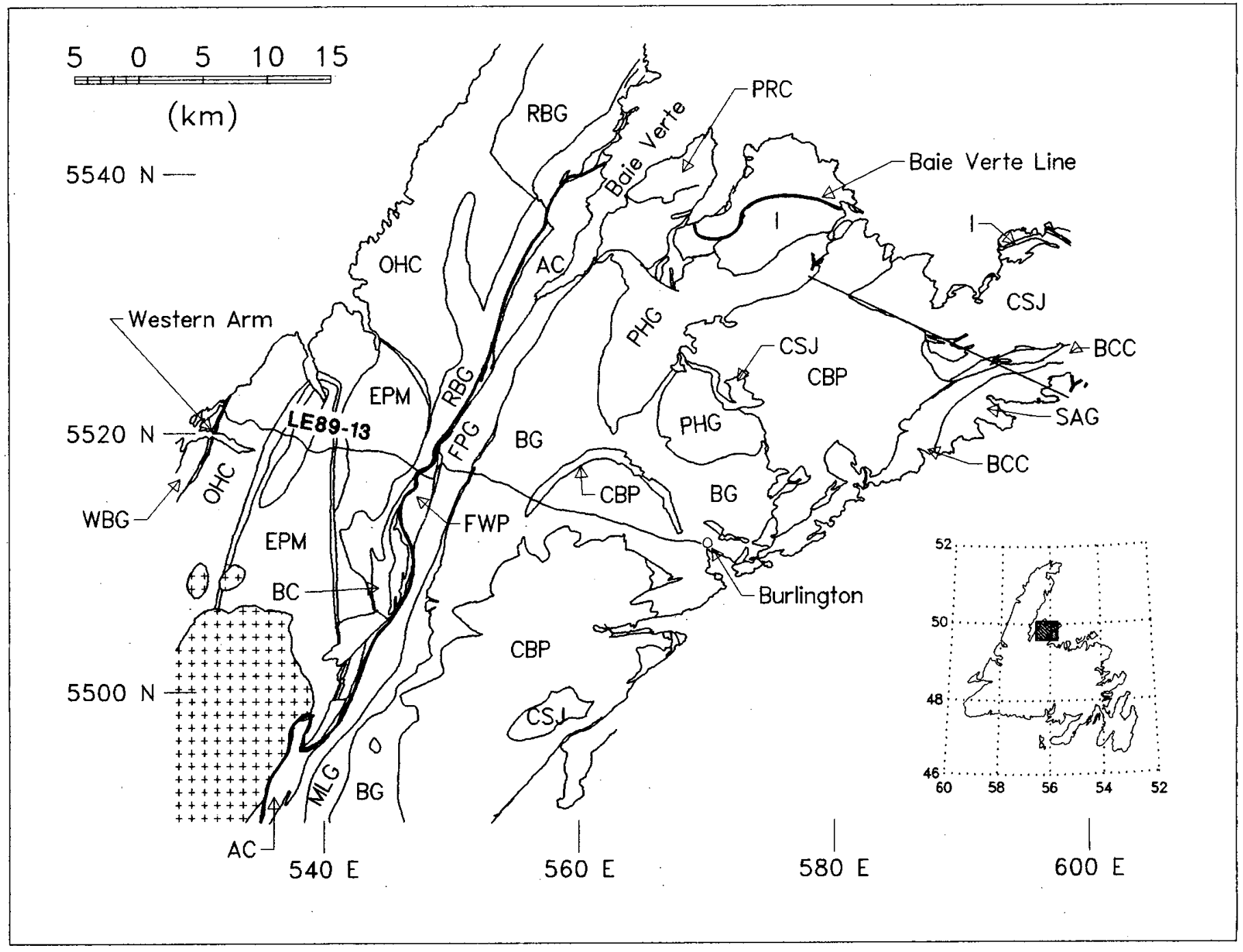

Fig. 1. General geology map of the Baie Verte Peninsula after Hibbard (1983). Location of Lithoprobe East Transect line LE89-13 is shown, as well as the modelled transect Y-Y'. The Baie Verte Line is expressed as the bold solid line, oriented approximately north-northeast through the center of the peninsula. Coordinates are in UTM Zone $21 \mathrm{~km}$. The hatched bodies are muscovite-bearing granite batholiths. Legend: AC = Advocate Complex, $\mathrm{BC}=$ Birchy Complex, $\mathrm{BCC}=$ Betts Cove Complex, $\mathrm{BG}=$ Burlington Granodiorite, $\mathrm{CBP}=\mathrm{Cape} \mathrm{Brule}$ Porphyry, CSJ = Cape St. John Group, EPM = East Pond Metamorphic Suite, FPG = Flatwater Pond Group, FWP = Flatwater Pond body (Advocate Complex), I = Silurian-Devonian intrusives, $\mathrm{MLG}=$ Micmac Lake Group, $\mathrm{OHC}=$ Old House Cove Group, PHG = Pacquet Harbour Group, PRC $=$ Point Rousse Complex, RBG = Rattling Brook Group, SAG = Snooks Arm Group, WBG = White Bay Group.

1979). This contact is a steeply faulted structural zone characterized by ophiolite occurrences on the east side.

The Baie Verte Line trends roughly north-northeast through the Baie Verte Peninsula. At Baie Verte, it assumes a more easterly direction and heads out to sea (Hibbard, 1983). Williams (1979), Williams and Hatcher $(1982,1983)$, and Williams $e t$ al. (1988) continued the Baie Verte Line southward to join the Long Range Fault in southwestern Newfoundland.

The Humber Zone rocks on the Baie Verte Peninsula, west of the Baie Verte Line, are composed of three main lithic elements: (1) local structural basement, (2) a metaclastic cover sequence, and (3) post-kinematic granitoid intrusions (Hibbard, 1983).

Structural basement is composed of migmatite, banded gneiss, and schist of the East Pond Metamorphic Suite (EPM) (Hibbard, 1983). The cover sequence consists mainly of metasedimentary rocks of the Old House Cove Group (OHC), Birchy Complex (BC), Rattling Brook Group (RBG), and the White Bay Group (WBG). In places these units were deposited on Grenville basement, whereas in other areas the contact is tectonic (Hibbard, 1983).

Both the structural basement and cover sequence have been post-tectonically intruded by a muscovite-bearing granite batholith.

Immediately to the east of the Baie Verte Line are rocks of the Dunnage Zone. These are composed of: (1) ophiolite suites and their corresponding volcanic cover sequences, and (2) intrusions.

The four ophiolitic units on the Baie Verte Peninsula (Advocate Complex (AC), Point Rousse Complex (PRC), Betts Cove Complex (BCC), and the Pacquet Harbour Group (PHG)) are considered mutually correlative, although they are geographi- 
cally separated, and are structurally different. The Pacquet Harbour Group consists only of the uppermost lavas of an ophiolite assemblage. The other ophiolite complexes are nearly complete.

Mafic volcaniclastic and volcanic rocks of the Flat Water Pond Group (FPG) comprise the Advocate Complex cover sequence, and pillow lavas of the Snooks Arm Group (SAG) cover the Betts Cove Complex (BCC) (Hibbard, 1983).

Silurian intrusions cut older rock units throughout the Baie Verte Peninsula. Most notable of the Silurian intrusions is the Burlington Granodiorite (BG), which covers much of the exposed area east of the Baie Verte Line.

Unconformably overlying the Burlington Granodiorite and the Flat Water Pond Group are the late Silurian to early Devonian dominantly silicic volcanic rocks of the Micmac Lake Group (MLG) (Hibbard, 1983). Silurian-Devonian subaerial volcanic and sedimentary rocks of the Cape St. John Group (CSJ) unconformably cover the Betts Cove Complex and cover sequence (Hibbard, 1983).

The Cape Brule Porphyry (CBP) is a large Silurian-Devonian intrusion cutting the Cape St. John Group, Burlington Granodiorite, and older rocks. Other Silurian-Devonian intrusions (I) of gabbro, syenite, diorite and leucogabbro, granite and quartz syenite, and granite intrude younger rocks to the northeast.

\section{Previous geophysical studies}

The Baie Verte Peninsula has been covered by Geological Survey of Canada standard aeromagnetic surveys; these aeromagnetic data have recently been regridded to $200 \mathrm{~m}$ spacing by Kilfoil and Bruce (1991). In addition, parts of the peninsula have been covered by high resolution aeromagnetic, VLF, and radiometric methods.

Gravity data on the peninsula were collected with a $2.5 \mathrm{~km}$ mean station spacing in the 1970s (Miller and Deutsch, 1976) and as part of a $13 \mathrm{~km}$ spacing survey of the whole island of Newfoundland (Weaver, 1967). As part of the Lithoprobe East transect, gravity data were collected every $1 \mathrm{~km}$ along seismic line LE89-13.

Gravity data were previously interpreted by Miller and Deutsch (1976) with additional interpretation in conjunction with the magnetic data and the offshore data undertaken by Haworth and Miller (1982). Haworth (1981) and Jacobi and Kristoffersen (1981) also discussed the more regional aspects of the gravity and magnetic data. The most fundamental conclusion to come from these studies was that the Baie Verte Line represents the westernmost extent of ophiolitic blocks in the upper $10 \mathrm{~km}$ of the crust. Haworth and Miller (1982) also demonstrated that this western edge could be followed northward from the Baie Verte Peninsula, and Miller and Morris (1988) and Miller (1990) attempted to correlate the gravity and magnetic signatures with the offshore Lithoprobe East line 84-2,3 northeast of the Baie Verte Peninsula.

Lithoprobe East seismic reflection line LE89-13 traversed the Flat Water Pond (FWP) ultramafic body of the Advocate Complex at the Baie Verte Line. To the east it crossed the Burlington Granodiorite (BG), and to the west the many metasedimentary units of the Humber Zone. A detailed discus- sion of the Lithoprobe East reflection experiment is provided in Quinlan et al. (1992).

\section{GeOPHYSICAL DATA FOR THIS STUDY}

The primary data sets analyzed in this study were all the Bouguer gravity data and the $200 \mathrm{~m}$ regridded aeromagnetic data for onshore and offshore areas, as well as the LE89-13 seismic data. A line drawing interpretation of LE89-13 is presented in Figure 2.

The gravity data were compiled and gridded on to a $5 \mathrm{~km}$ grid for use in processing (Fig. 3). The original data spaced at 1 $\mathrm{km}$ along the Lithoprobe line and the data spaced at $2.5 \mathrm{~km}$ along other roads were utilized in modelling to provide as much detail as possible. The magnetic profile data were sampled at a similar spacing.

The magnetic anomaly map (Fig. 4) was reduced to the magnetic pole for further processing operations. This operation is undertaken to remove the inherent asymmetry in magnetic anomalies due to the orientation of the earth's magnetic field (Bhattacharyya, 1965).

The gravity and magnetic maps (Figs. 3,4 ) provide a basis for interpretation but modern map processing techniques enable much more information to be extracted from the resulting maps. The most commonly used maps are (1) horizontal and vertical derivative maps which emphasize geophysical features associated with boundaries between units and highlight directional trends, (2) shaded relief maps in which the potential field is treated as relief and illuminated from particular directions to detect trends, and (3) various filtering operations which enable the processor to assess the contribution to the potential field from sources at various depths. For a more complete discussion of their use in this study the reader is referred to R. Wiseman, in preparation.

A fundamental requirement for the modelling of potential field data is knowledge of density and magnetic susceptibility of rocks in the area. The major rock units in the area were sampled as part of earlier projects (Wiseman, 1991; Miller and Deutsch, 1976) and additional samples of specific units were collected as part of the present study. These data are summarized in Table 1.

\section{Observations}

\section{Seismic data}

Although the Baie Verte Line has been geologically interpreted as a near-vertical major tectonic boundary between the Humber Zone and Dunnage Zone, it does not manifest itself in this manner on the migrated deep-seismic data of Lithoprobe East line 89-13 (Fig. 2). Here, the Baie Verte Line (BVL) appears to be a shallow east-dipping reflector which cannot be directly tied to the surface due to a lack of coherent reflections in the upper $0.2 \mathrm{~s}$ two-way travel time $(0.6 \mathrm{~km}$, assuming average velocity of $6 \mathrm{~km} / \mathrm{s}$ ).

Figure 2 shows many shallow east-dipping reflectors $(E)$, predominantly in the upper part of the section which are cut at lower crustal levels by west-dipping reflectors (W) that appear 

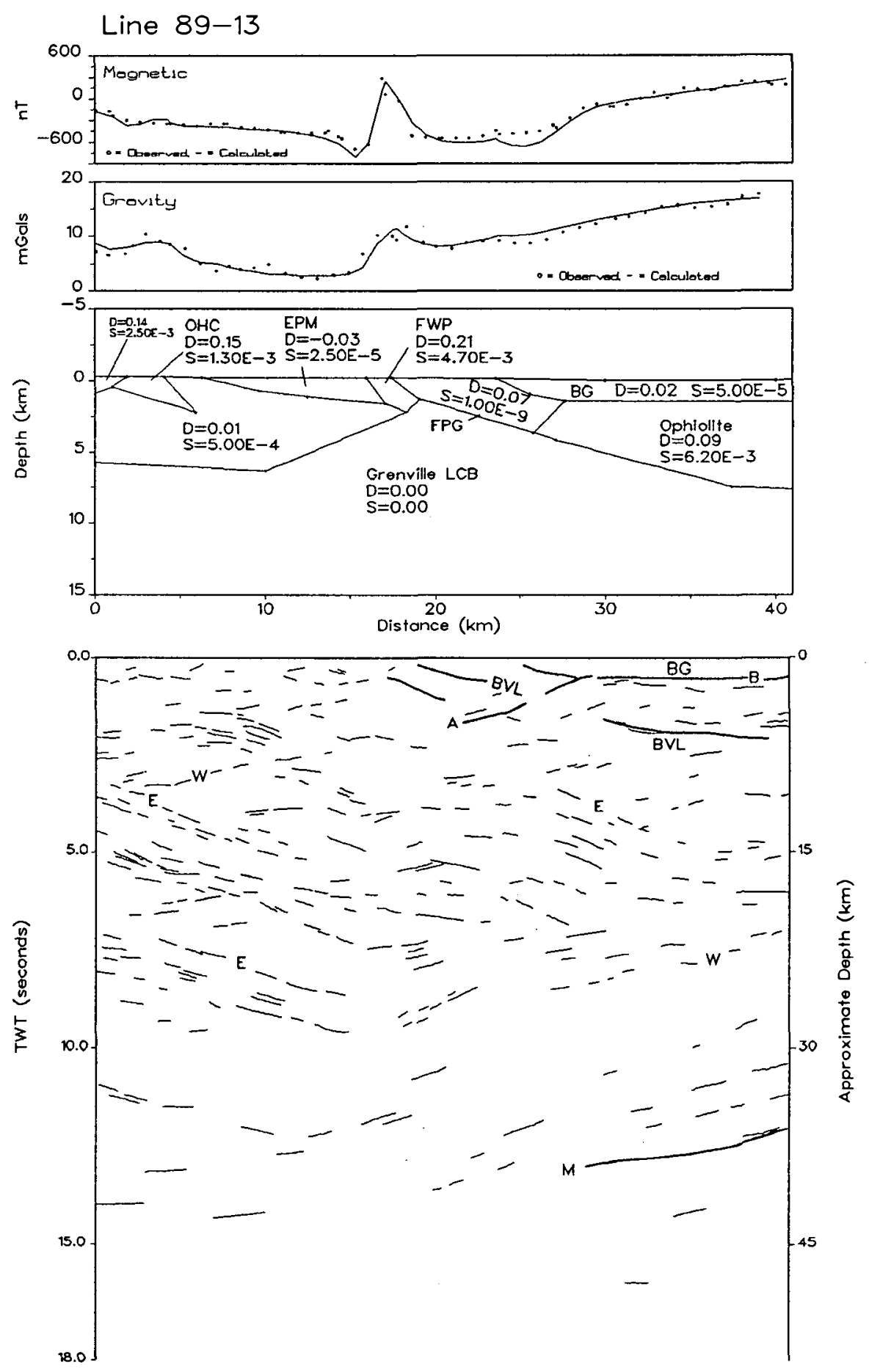

Fig. 2. Seismic line drawing and 2.5-D gravity and magnetic model for Lithoprobe East Line 89-13. The seismic line drawing interpretation shows a series of west-dipping reflectors $(W)$ and east-dipping reflectors $(E)$. The Moho $(M)$ is seen in the eastern half of the section, dipping west. The Baie Verte Line (BVL) is an east-dipping shallow fault. The 2.5-D model is the same for both gravity and magnetic data. Legend: A = west dipping reflector mentioned in the text, $\mathrm{B}=$ base of the Burlington Granodiorite, $\mathrm{BG}=$ Burlington Granodiorite, $\mathrm{D}=$ density contrast relative to $2.67 \mathrm{~g} / \mathrm{cm}^{3}, \mathrm{EPM}=$ East Pond Metamorphic Suite, FPG = Flat Water Pond Group, FWP = Flatwater Pond body of the Advocate Complex, $\mathrm{OHC}=$ Old House Cove Group, $\mathrm{S}=$ magnetic susceptibility in c.g.s. units.

to cross the entire section and may also cut the Moho (M). Another west-dipping reflector $(A)$ in the upper part of the section appears to cut the Baie Verte Line (BVL). This reflector, although it cannot be traced to the surface, is coincident with some small-scale faulting in the Burlington Granodiorite (BG) and Cape Brule Porphyry when projected to the surface
(Jamieson et al., 1993). These small-scale faults may represent late movements on this crustal-scale fault.

A near-horizontal reflector (B) is present at 0.5 seconds two-way travel time $(1.5 \mathrm{~km})$ in the eastern part of the section which may represent the base of the Burlington Granodiorite (Fig. 2). 


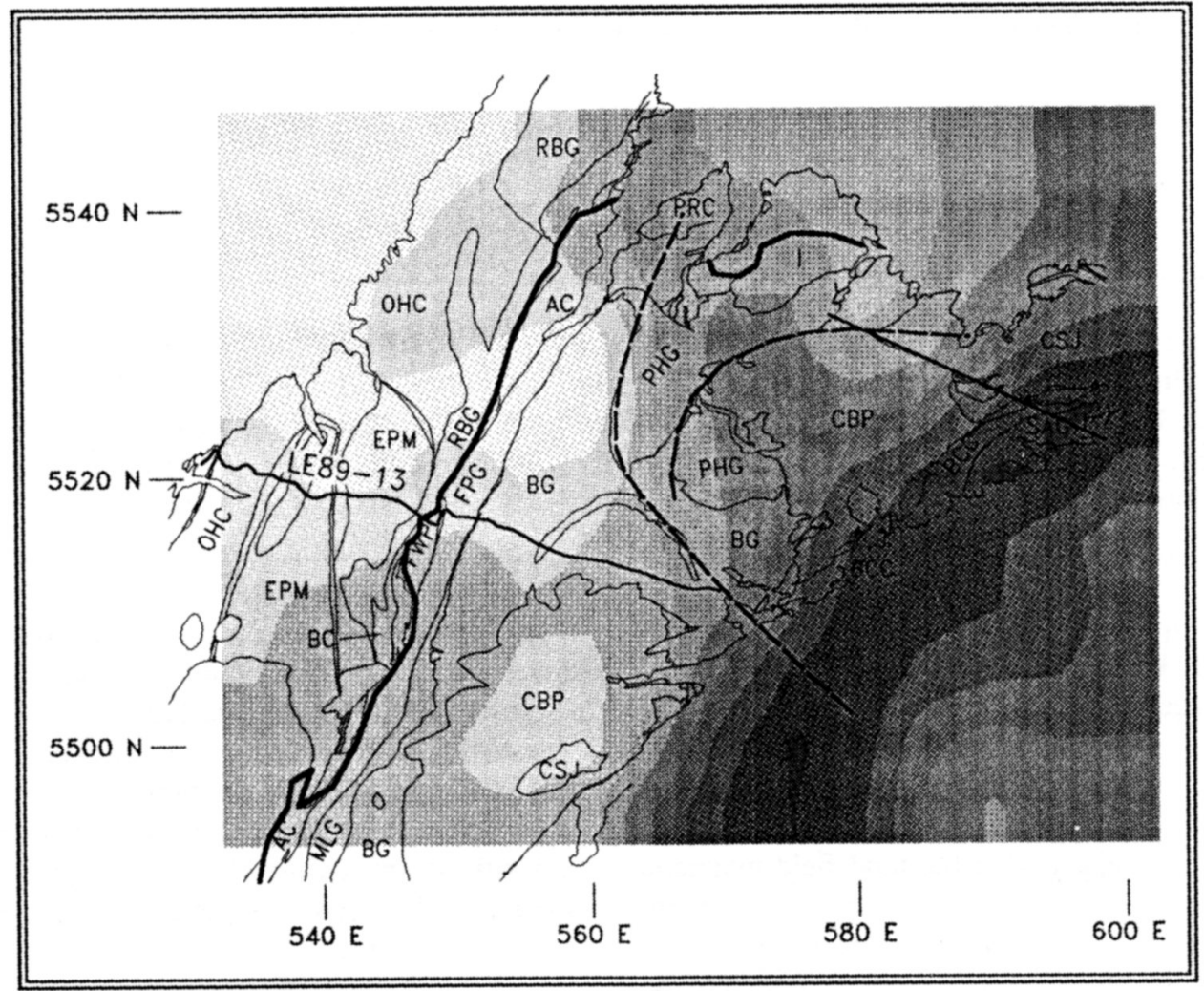

Fig. 3. Gravity map for the Baie Verte Peninsula. The map is based upon a $5 \mathrm{~km}$ grid with a linear gray scale ranging from light (< $5 \mathrm{mGal})$ to dark $(>40 \mathrm{mGal}$ ) at $5 \mathrm{mGal}$ divisions. Coordinates are in UTM Zone $21 \mathrm{~km}$. The geology (Hibbard, 1983) is overlain on the gravity image as solid black lines. The Baie Verte Line is expressed by the thick solid black line. Seismic line LE89-13 is also shown on the map, and the thick dashed line is the magnetically defined splay fault boundaries of the thrust sheet emplacing the Pacquet Harbour Group. The symbols follow the legend of Figure 1.

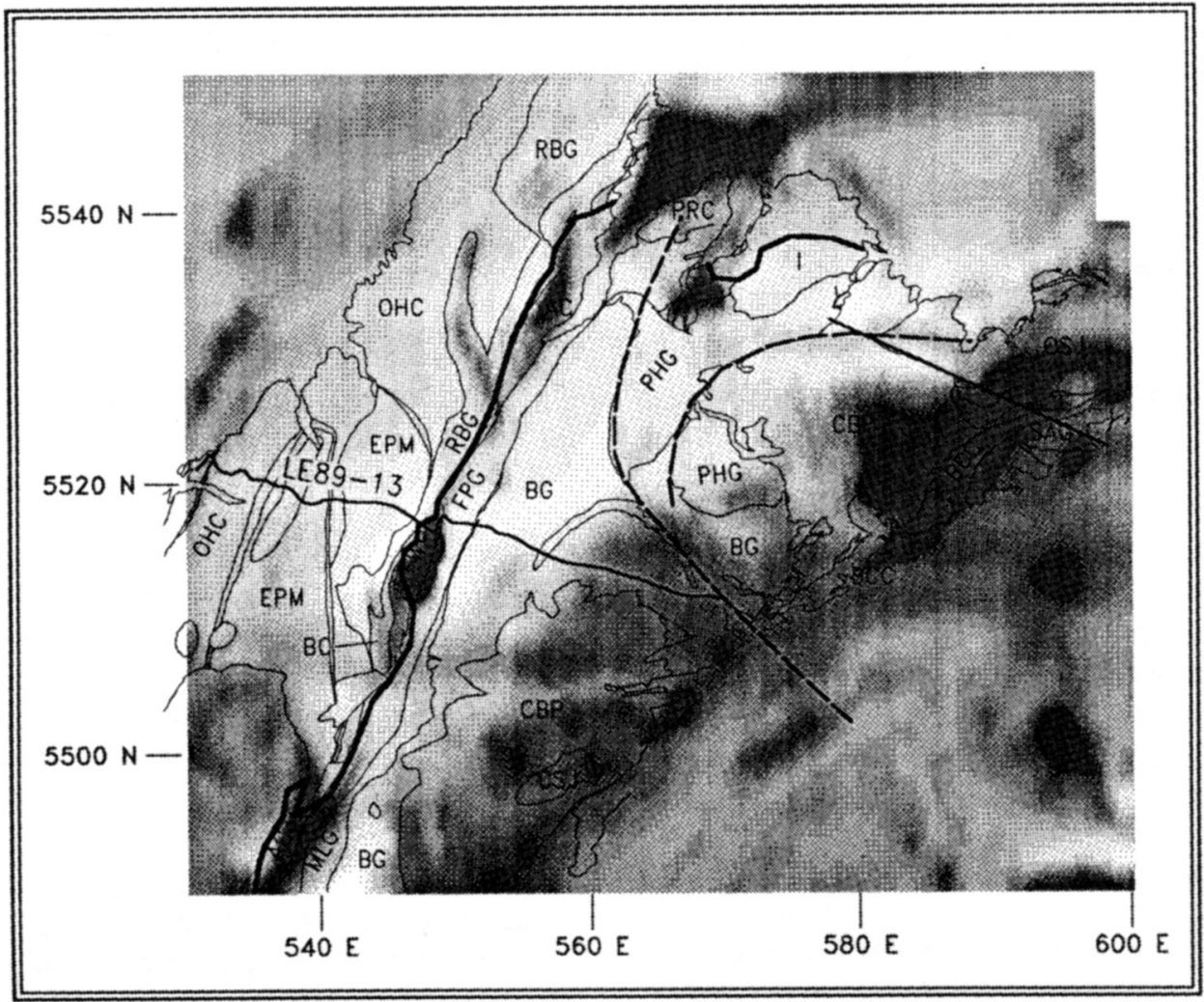

Fig. 4. Total field magnetic map with equal area gray-shade scaling for the Baie Verte Peninsula. Equal area scaling is a process by which mapped values are binned to produce a map in which all colors or gray-shades cover an equivalent area on the map. This process is good for presenting data with a large dynamic range. Here values range from light $(<-575 n \mathrm{nT})$ to dark $(>400 \mathrm{nT})$ at $25 \mathrm{nT}$ divisions. Coordinates are in UTM Zone 21 $\mathrm{km}$. The legend follows that of Figure 1 . 
Table 1. Physical property data for rocks of the Baie Verte Peninsula

\begin{tabular}{|c|c|c|c|c|c|c|}
\hline Unit & $\begin{array}{l}\text { Mean } \\
\text { Dens. } \\
\left(\mathrm{g} / \mathrm{cm}^{3}\right)\end{array}$ & $\begin{array}{l}\text { Std. } \\
\text { Dev. }\end{array}$ & $\mathrm{N}$ & $\begin{array}{l}\text { Mean } \\
\text { Susc. } \\
\text { (c.g.s.) }\end{array}$ & $\begin{array}{l}\text { Std. } \\
\text { Dev. }\end{array}$ & $\mathrm{N}$ \\
\hline Cape Brule Porphyry & 2.64 & 0.02 & 6 & $3.40 \times 10^{-4}$ & $4.32 \times 10^{-4}$ & 16 \\
\hline Burlington Granodiorite & 2.69 & 0.04 & 6 & $1.88 \times 10^{-5}$ & $1.05 \times 10^{-5}$ & 24 \\
\hline East Pond Metamorphic Suite & 2.70 & 0.05 & 5 & $3.28 \times 10^{-5}$ & $3.34 \times 10^{-5}$ & 18 \\
\hline Flatwater Pond body & 2.74 & 0.13 & 47 & $2.46 \times 10^{-3}$ & $2.11 \times 10^{-3}$ & 36 \\
\hline White Bay Group & 2.73 & 0.02 & 3 & $3.56 \times 10^{-5}$ & $2.70 \times 10^{-5}$ & 9 \\
\hline
\end{tabular}

The Moho $(M)$ dips west between 12 to 13 seconds twoway travel time $(36-39 \mathrm{~km})$ in the eastern portion of the seismic profile, but is not imaged near the center of the profile.

\section{Magnetic data}

The Baie Verte Line appears on the total field magnetic anomaly map (Fig. 4) as a strong linear, relative magnetic high, trending north-northeast - south-southwest, with a series of discrete very high anomalies over exposed ultramafic bodies of the Advocate Complex (e.g., the Flat Water Pond body). The lower amplitude anomaly along the Baie Verte Line between the ultramafic bodies is likely due to graphitic schist of the Rattling Brook Group exposed there.

Two shaded relief maps were produced, one with an illumination direction angle of $125^{\circ}$ azimuth and $45^{\circ}$ inclination (Fig. 5) which is approximately perpendicular to the Baie Verte Line, and the other with an illumination direction angle of $40^{\circ}$ azimuth and $45^{\circ}$ inclination (Fig. 6). These maps are useful for enhancing detail within anomaly patterns. The first map enhances features parallel to the Baie Verte Line, and the second illuminates features perpendicular to it.

Upward continuation maps were produced for elevations of $3,6,10$ and $15 \mathrm{~km}$, and the depth separation filtering method of Jacobson (1987) was used to produce maps of anomalies with sources in the 0 to $1.5,1.5$ to 3,3 to 5 , and 5 to $7.5 \mathrm{~km}$ depth ranges. The depth separation filtering method described by Jacobson (1987) is based on the wavelength versus source depth relation of magnetic anomalies, and involves subtraction of the resultant magnetic fields after upward continuation to two elevations. Assuming a sandwich source distribution, Jacobson (1987) found that the field originating from sources within a particular depth range $\left(z_{1}\right.$ to $z_{2} ; z$ is positive downward) is equivalent to the field continued upward to a height of $2 z_{2}$ subtracted from the field continued upward to a height of $2 z_{1}$. Only the depth separation maps for anomalies with sources between 1.5 to $3 \mathrm{~km}$ (Fig. 7) and 5 to $7.5 \mathrm{~km}$ (Fig. 8) depth ranges are reproduced here.

The anomaly associated with the Flat Water Pond body (FWP) is seen to disappear with increasing depth to source (Figs. $7,8)$. This indicates that the body is a shallow feature within the upper $5 \mathrm{~km}$ of the crust.

A large magnetic anomaly occurs beneath Baie Verte, roughly outlined by the coastline of the bay (Fig. 4). This, combined with observed peridotite exposure on islands in the bay, suggests that the bay is underlain by ophiolitic rocks.

Along the whole eastern margin of the Baie Verte Peninsula is a large irregular magnetic high (Fig. 4). There appears to be a change in character of this anomaly pattern from north to south at approximately $55^{\circ} 20^{\prime} \mathrm{N}$. Toward the north, the anomaly is higher amplitude and more continuous than in the south. The anomaly appears to terminate abruptly on its eastern edge at the coast of the peninsula (Green Bay Fault). On its western edge, this anomaly does not correlate with any surface geologic boundary on the geology map compiled by Hibbard (1983).

The magnetic shaded relief map with illumination azimuth of $125^{\circ}$ (Fig. 5), shows that the Betts Cove Complex is responsible for a magnetic anomaly superimposed upon part of this larger anomaly. This is evident from the dark area along the western edge of the Betts Cove Complex.

Within this anomaly pattern there is a distinct step in the magnetic anomaly amplitude (about $300 \mathrm{nT}$ ) at about $25 \mathrm{~km}$ eastward along the seismic line (Figs. 2, 4). It is also highlighted quite distinctly by a dark area on the magnetic shaded relief map with false sun illumination angle of $125^{\circ}$ (Fig. 5). This is coincident with the location of the eastern part of a westdipping reflector that appears to cut the Baie Verte Line on the seismic data (reflector 'A' on Fig. 2), where the physical property contrast is significant between volcanic rocks of the Flat Water Pond Group and the tectonically emplaced ophiolitic rocks. This diagnostic step in the magnetic data can be used on the magnetic map (Fig. 4) to trace this subsurface feature northeast and southwest from the control of the seismic line.

Also visible on the total field magnetic map (Fig. 4) is a series of arcuate magnetic highs which follow the edges of the Pacquet Harbour Group. These anomalies may be the result of magnetite generation due to alteration along the boundary of these volcanic rocks. The magnetic trends can be traced into a linear, southeast-trending, magnetic high which crosses Notre Dame Bay to the east, and can be traced farther north than the areal extent of the Pacquet Harbour Group (PHG). They are also indicated by dark areas on the magnetic shaded relief maps (Figs. 5, 6). These trends are highlighted on the maps with a dashed black line. 


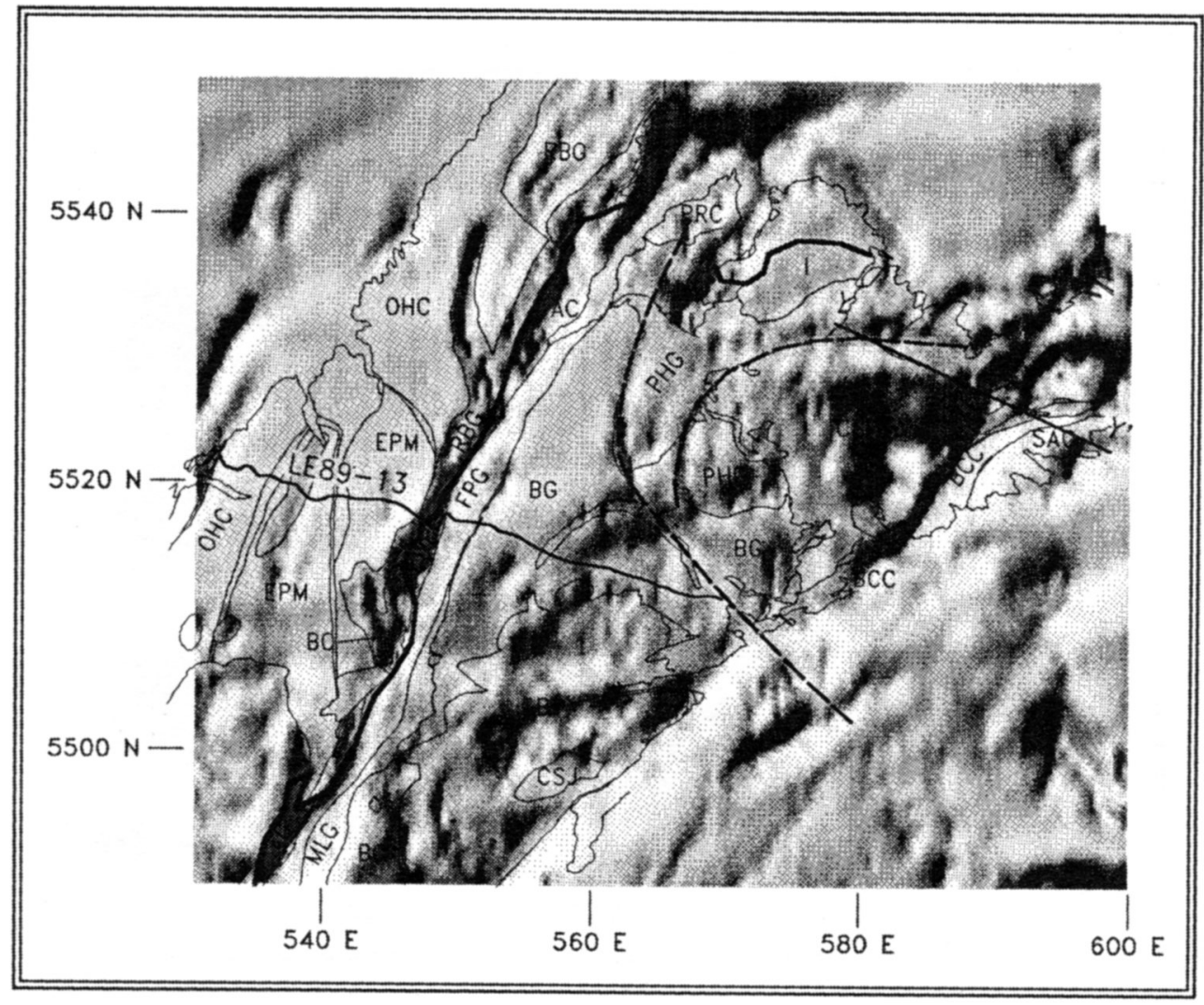

Fig. 5. Shaded relief image of the Baie Verte Peninsula magnetic map with illumination angle $A=125^{\circ}, I=45^{\circ}$. Legend follows that of Figure 1 .

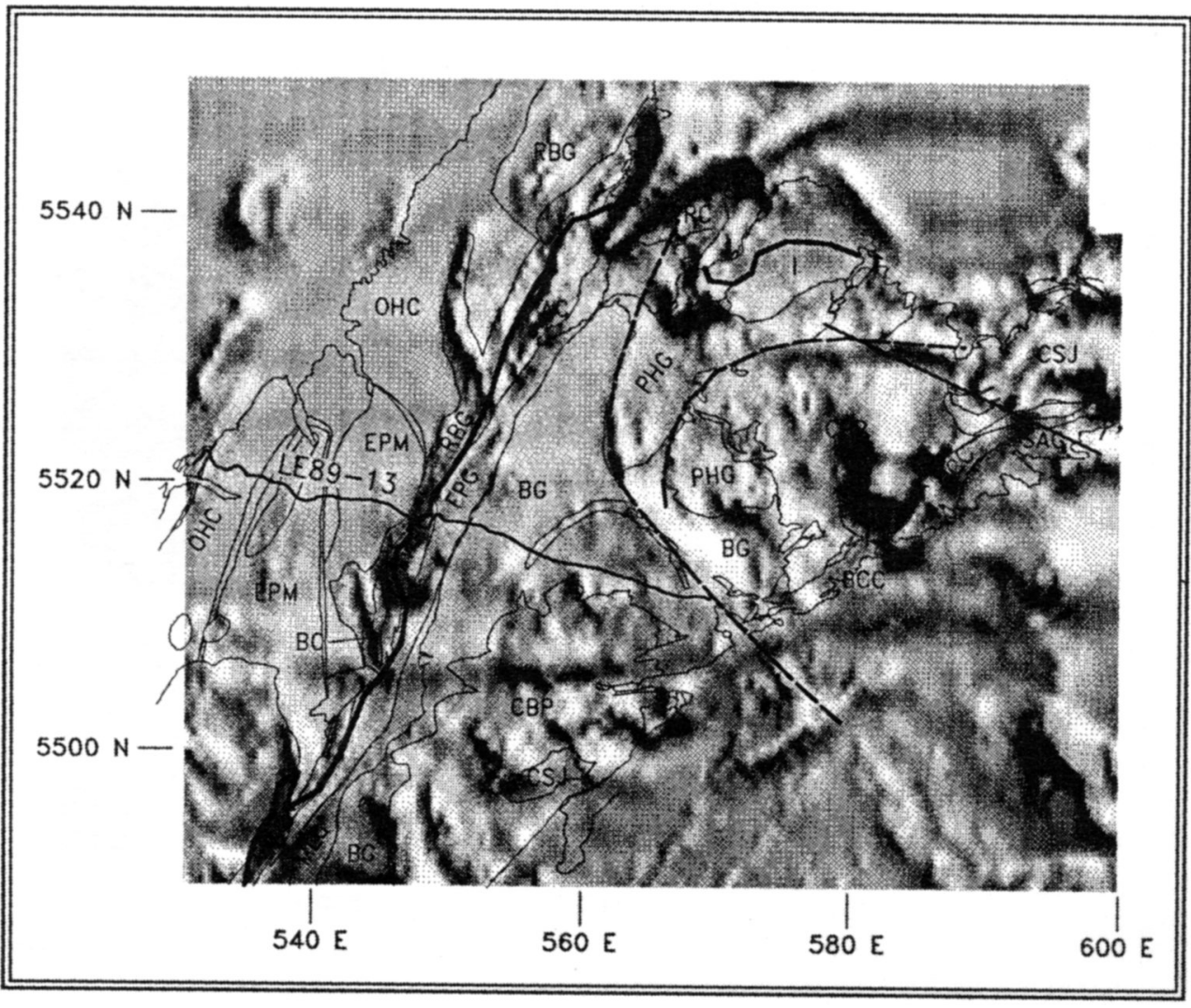

Fig. 6. Shaded relief images of the Baie Verte Peninsula magnetic map with illumination angle $A=40^{\circ}, I=45^{\circ}$. Legend follows that of Figure 1 . 


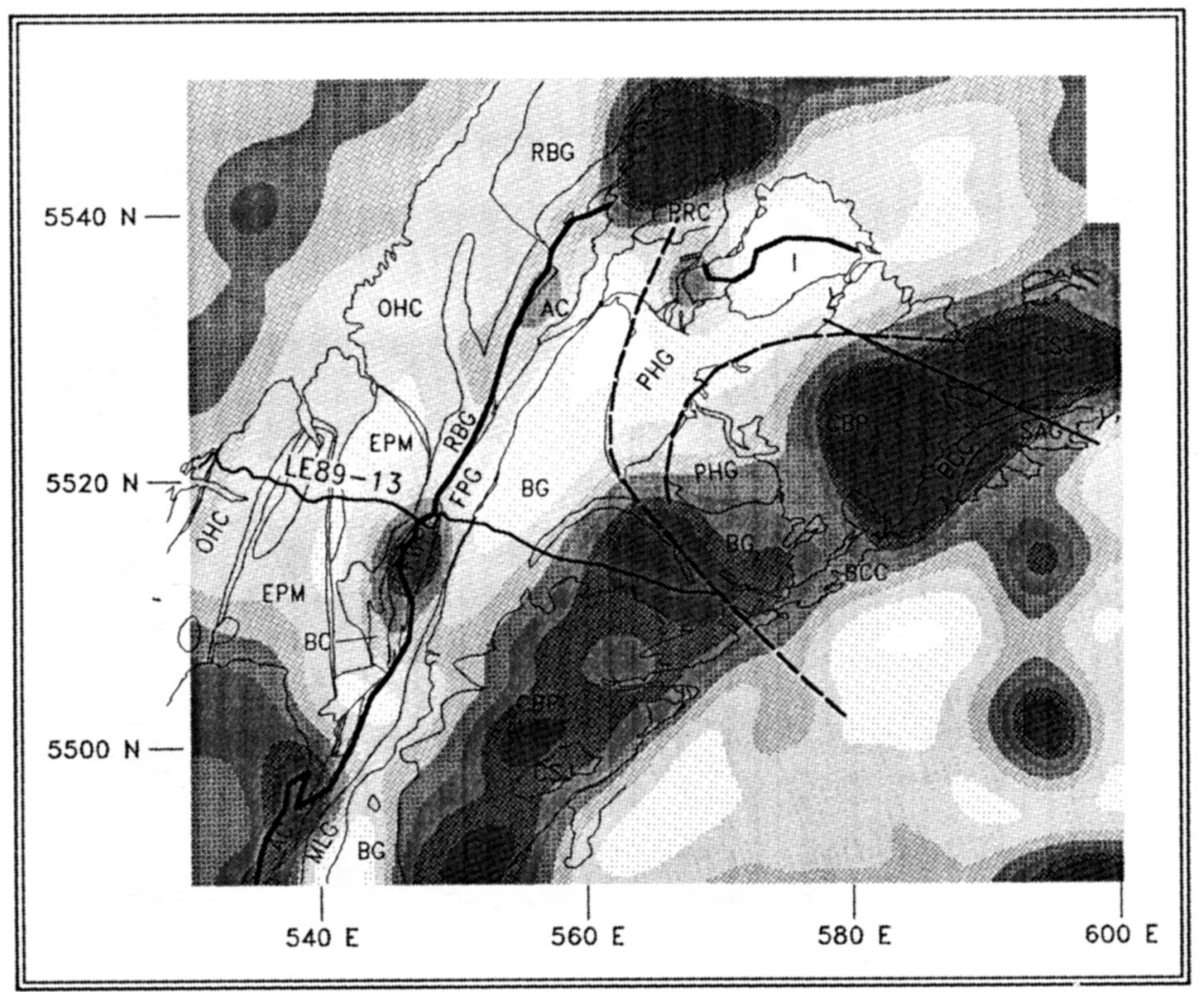

Fig. 7. Magnetic layer strip map of the magnetic field resulting from sources between $1.5 \mathrm{~km}$ and $3 \mathrm{~km}$ depth. Color scale ranges from light $(<-75$ $\mathrm{nT})$ to dark (>75 nT) at $25 \mathrm{nT}$ divisions. The legend follows that of Figure 1.

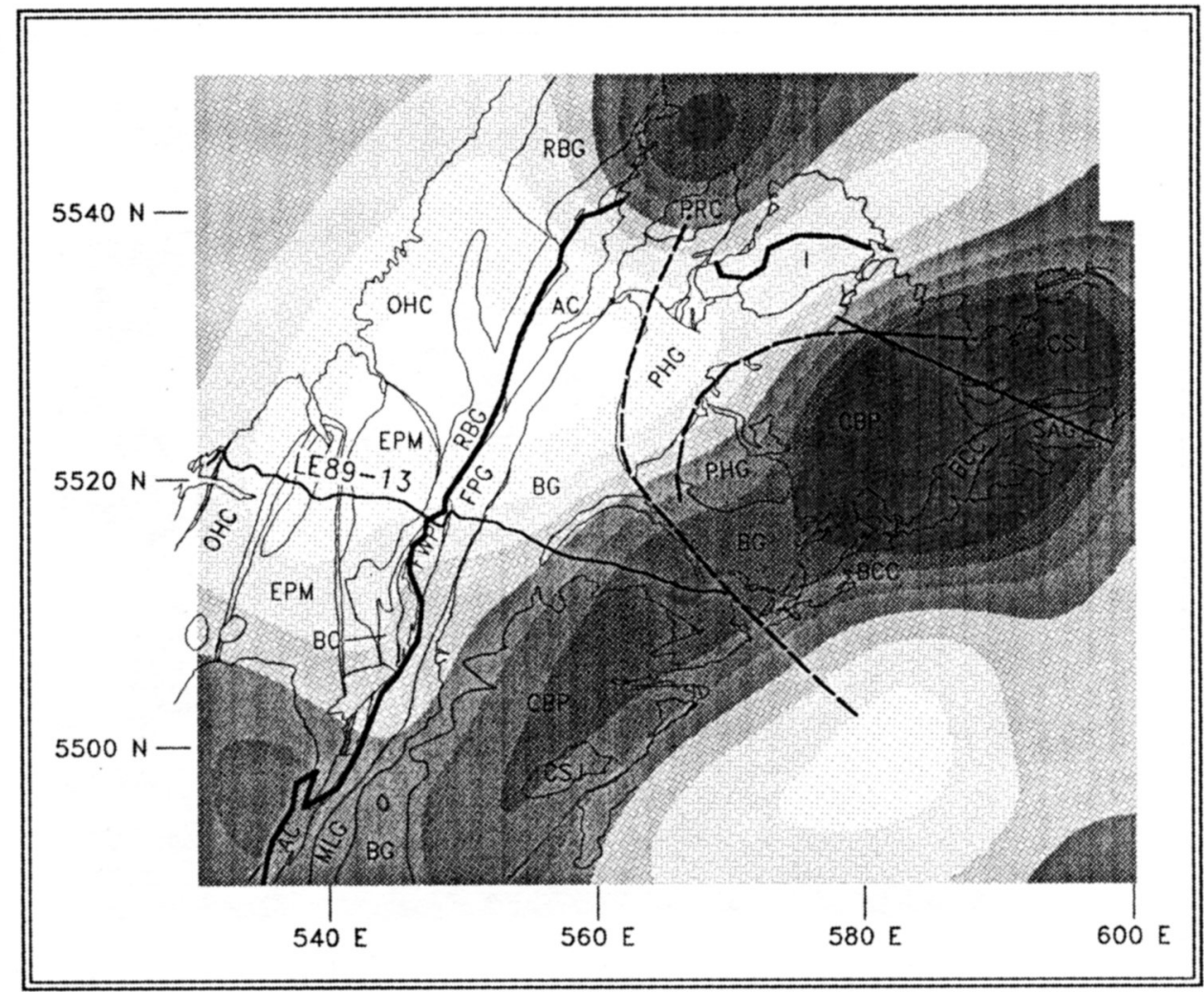

Fig. 8. Magnetic layer strip map of the magnetic field resulting from sources between $5 \mathrm{~km}$ and $7.5 \mathrm{~km}$ depth. Color scale ranges from light (<-30 $\mathrm{nT})$ to dark (> $30 \mathrm{nT})$ at $10 \mathrm{nT}$ divisions. The legend follows that of Figure 1. 


\section{Gravity data}

The gravity field (Fig. 3) shows a general regional trend from high in the southeast to low in the northwest. There is a positive anomaly over the Pacquet Harbour Group (PHG) and an indication of a gravity high over the Baie Verte Line to the south of the Flat Water Pond body.

In order to examine the residual gravity field which correlates with near surface features, the regional gravity field was subtracted from the total field. The regional field was removed by applying a Gaussian regional/residual filter which rejected the long wavelength anomalies (Fig. 9). The most noticeable feature in the residual gravity maps for the Baie Verte Peninsula is the distinct gravity high over the Betts Cove Complex (BCC), which continues toward the southwest beneath Notre Dame Bay. This indicates that the rocks of the Betts Cove Complex are denser than the surrounding rocks. The positive anomaly over the Flatwater Pond body is emphasized on the residual map.

Another interesting feature on the residual gravity map is a roughly linear high trending north-northwest which covers the area of the Pacquet Harbour Group and crosses the Baie Verte Line. It is near this location that Hibbard (1983) noted that the Baie Verte Line turns sharply east.

\section{Modelling}

In order to ascertain the correlation between the scismic section and the potential field data, the potential field data along the Lithoprobe East line 89-13 were modelled using a 2.5-D modelling package. The physical property data from Table 1 were used to assign densities and susceptibilities to the bodies identified on the seismic section. The resulting composite model is shown in Figure 2. Essentially all of the observed gravity and magnetic anomalies can be explained by sources within the upper $10 \mathrm{~km}$ of the crust.

The Flat Water Pond body of the Advocate Complex is responsible for the gravity and magnetic high near the center of the profile and defines the potential field response of the Baie Verte Line on the profile. For modelling purposes, this body was required to have an assigned density contrast of $0.21 \mathrm{~g} /$ $\mathrm{cm}^{3}$ relative to $2.67 \mathrm{~g} / \mathrm{cm}^{3}$ and a magnetic susceptibility of 4.70 $\times 10^{-3}$ c.g.s. units. The density is at the upper limit of the measured density data (Table I), but at greater depths in the body serpentinization may be less extensive than near the surface. The effect of this would be higher densities with depth, so the modelling density is not considered excessive. The required magnetic susceptibility for this body is also higher than the average value presented in Table I, but it should be noted that the tabulated value includes many talc and magnesite-talc alteration samples which comprise only a small percentage of the exposed Flat Water Pond body. This type of alteration consumes magnetite (Wiseman, 1991) and biases the average susceptibility towards low values. The true average magnetic susceptibility is likely considerably higher.

The other major feature modelled on LE89-13 is a block of high density $(\Delta \rho=0.09)$ and high magnetic susceptibility (6.20 $\times 10^{-3}$ c.g.s. units), interpreted as an ophiolitic sheet, beneath the Burlington Granodiorite. The western edge of this body coincides with the step in both the gravity and magnetic profiles

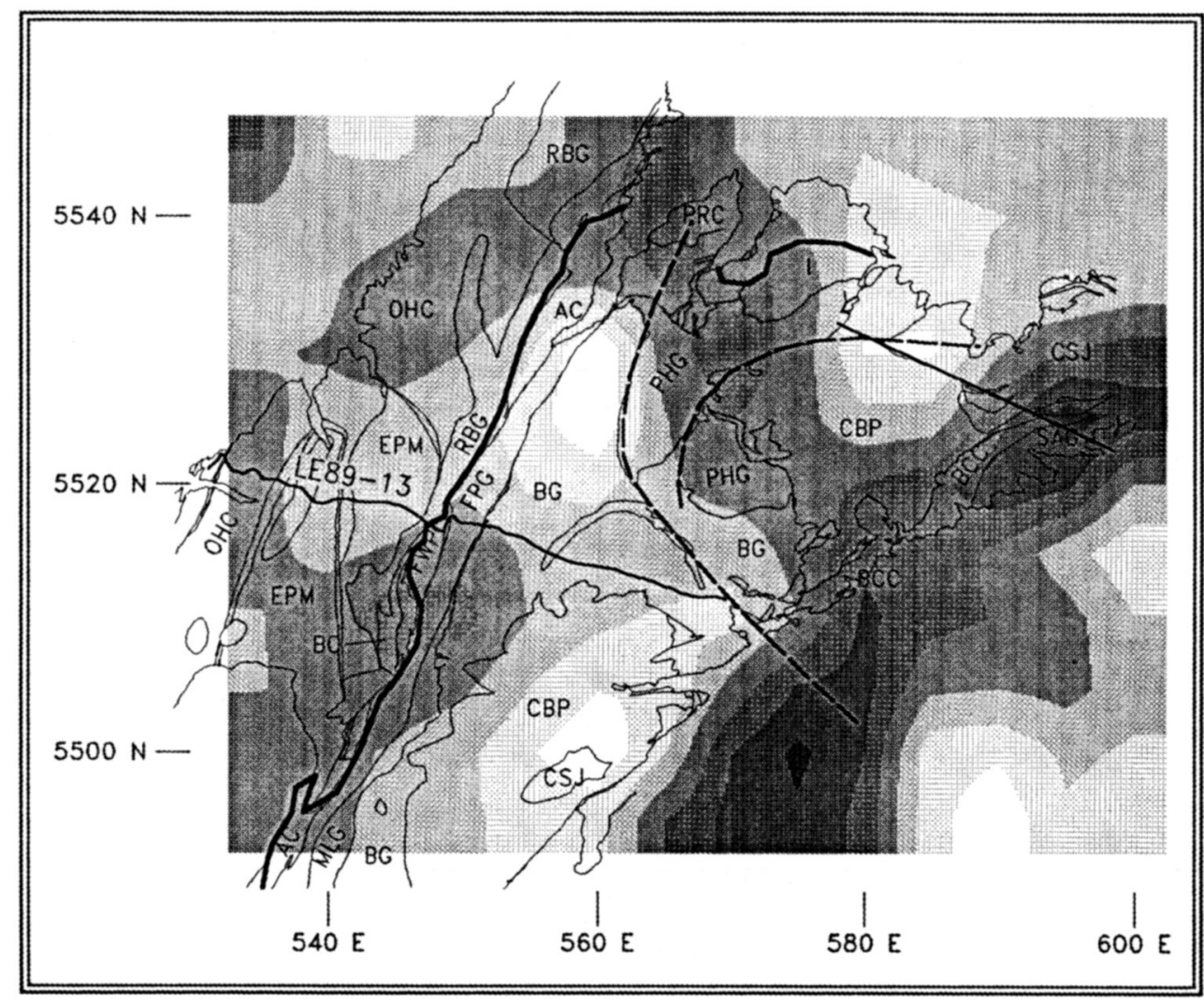

Fig. 9. Residual gravity map for the Baie Verte Peninsula resulting from applying a gaussian reject filter with central peak at $0.025 \mathrm{cycles} / \mathrm{km}$. The color scale ranges from light $(<.5 \mathrm{mGal})$ to dark $(>7.5 \mathrm{mGal}$ ) with $2.5 \mathrm{mGal}$ divisions. The legend follows that of Figure 1 . 
and with a west-dipping reflector (' $A$ ') on the seismic reflection profile.

In order to examine the validity of the model elsewhere on the peninsula, a profile, $Y-Y^{\prime}$, similar to the eastern part of 8913, was extracted farther north (Figs. 1, 10). This profile essentially parallels the first, is near the profile modelled by Miller and Deutsch (1976), and ends over the Betts Cove ophiolite. Two similarly oriented profiles were interpreted offshore by Haworth and Miller (1982). The model for this profile is similar in geometry and physical properties to $89-13$, but the sources extend to greater depths. The western extent of the body causing the step pattern is still seen on this model beneath the Cape St. John volcanics, Burlington Granodiorite, Betts Cove Complex, and Snooks Arm Group.

\section{INTERPRETATION}

The Vibroseis data indicate that the Baie Verte Line is a shallow east-dipping fault, with possibly later extension along reflector A (Fig. 2) after the initial thrusting. Potential field processing and modelling indicate that the Flat Water Pond ultramafic body, which parallels the Baie Verte Line, is east dipping and is confined to the upper $5 \mathrm{~km}$ of the Earth's crust because the Baie Verte Line is not observed on the equivalent source maps for greater depths. The general configuration of the Flat Water Pond body in the modelling is consistent with the latest structural models proposed by Jamieson et al. (1993).

The magnetic and gravity highs on the eastern half of the Baie Verte Peninsula are interpreted to be due to the subsurface extent of an intact oceanic crust thrust slice emplaced from the east. At the base of this unit is the ophiolite sole thrust defining the Baie Verte Line. This interpretation is consistent with local geology, as ultramafic inclusions are found in the Cape Brule Porphyry (Hibbard, 1983), indicating that the porphyry intruded the previously emplaced ophiolite sheet. As the Cape Brule Porphyry is Silurian-Devonian, the thrusting must have been older.

The potential field data and modelling demonstrate that the gravity and magnetic signature associated with the thrust sheet do not continue all the way westward to the surface exposure of the Baie Verte Line. Therefore, the ultramafic rocks which form the Flat Water Pond body and other bodies of the Advocate Complex must be dismembered slivers of ophiolite separated from the rest of the thrust sheet. This was likely accomplished by later extensional faulting throughout the region (Jamieson et al., 1993), which may be manifested as west-dipping features such as ' $A$ ' on the seismic section (Fig. 2).

The arcuate magnetic anomalies tracing the edge of the Pacquet Harbour Group, as mentioned previously, are interpreted
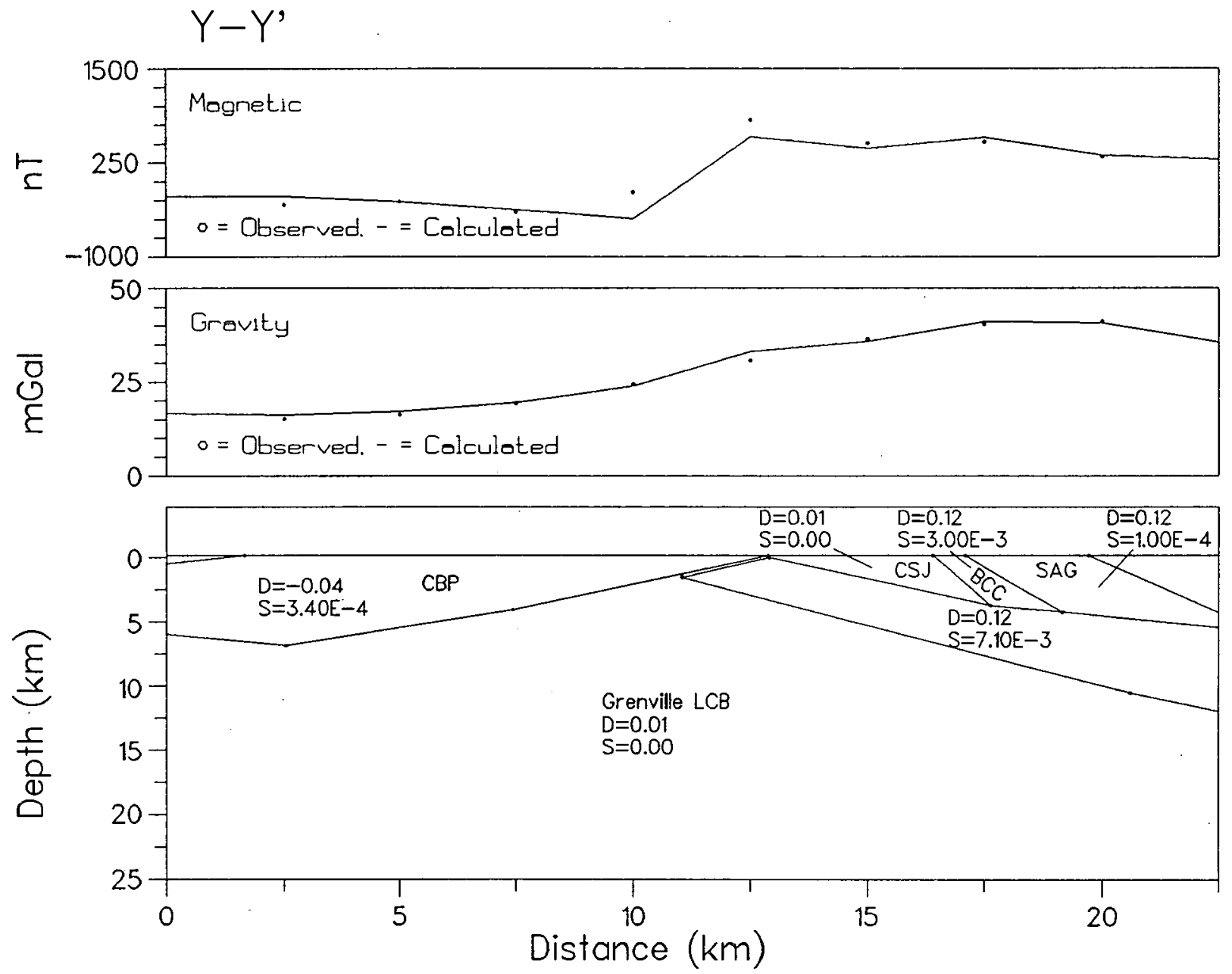

Fig. 10. 2.5-D gravity and magnetic model for transect $Y-Y^{\prime}$. Legend: $D=$ density contrast relative to $2.67 \mathrm{~g} / \mathrm{cm}^{3}, \mathrm{~S}=$ magnetic susceptibility in c.g.s. units, $\mathrm{BCC}=$ Betts Cove Complex, $\mathrm{CBP}=$ Cape Brule Porphyry, CSJ $=$ Cape St. John Group, SAG = Snooks Arm Group. 
as defining the splay fault boundaries of the imbricate fan, where this ophiolite unit and possibly also the Point Rousse Complex were upthrust. Although the Pacquet Harbour Group and the Point Rousse Complex are considered separate ophiolites, the lavas of the Pacquet Harbour Group are chemically correlative with equivalent lavas of the Betts Cove Complex and the Point Rousse Complex (Hibbard, 1983), so it is not unreasonable to interpret them as being part of the same thrust sheet.

\section{SUMMARY AND CONCLUSIONS}

Modelling and interpretation of the processed data indicate that the magnetic and gravity signatures can be explained by sources in the upper $10 \mathrm{~km}$ of the crust. The sources reflect the complex geological history of the area in their geometry. Deeper features are evident on the seismic section, but the use of physical properties consistent with samples collected at the surface suggests that only features in the upper crust contribute to the potential field signatures observed.

The general geometry of the model derived from the combined gravity, magnetic and seismic data is similar to the earlier models derived from potential field data alone (Miller and Deutsch, 1976; Haworth and Miller, 1982). The Baie Verte Line is a west-directed sole thrust of an imbricate thrust stack containing ophiolite material at the base. There appears to be more imbrication, or possibly more movement along the splays, toward the northern part of the peninsula.

The correlation between the major step in the potential field data on the eastern part of the peninsula with the west-dipping reflector ('A') on the seismic section, enables us to trace the locus of that feature throughout the study area and to confidently link it via the modelled lines and maps of Haworth and Miller (1982) to the Lithoprobe east Line 84-2 to the north. The earlier models based only on potential field data (Miller and Deutsch, 1976; Haworth and Miller, 1982) deduced the same source geometry as those of the present study which have the advantage of being confirmed by seismic reflection information.

The processed magnetic field maps reveal details of features on a fairly small scale which may be of importance when assessing the economic mineral potential of the area. Considerable detailed correlation can be done in this regard.

\section{ACKNowledgements}

This research was supported in part by Lithoprobe Supporting Geoscience grants to H.G. Miller and J.P. Hodych for the determination of physical properties of samples collected along the Lithoprobe lines in Newfoundland, and to a group led by H.G. Miller for the processing and interpretation of the potential field data near the Lithoprobe East reflection lines in Newfoundland. R. Wiseman received support in the form of a Newfoundland Offshore Fund Career Development Award. The research was also supported in part by an NSERC operating grant to H.G. Miller. We thank reviewers B. Loncarevic and W. Thomas for their helpful comments and suggestions.
Bhattacharyya, B.K. 1965. Two-dimensional harmonic analysis as a tool for magnetic interpretation. Geophysics, 30, pp. 829-857.

HawORTH, R.T. 1981. Geophysical expression of AppalachianCaledonian structure on the continental margin of the North Atlantic. In Geology of the North Atlantic borderlands. Edited by J. Wm. Kerr and A.J. Ferguson. Canadian Society of Petroleum Geologists, Memoir 7, pp. 429-446.

HAWORTH, R.T. and MiLler, H.G. 1982. The structure of Paleozoic oceanic rocks beneath Notre Dame Bay, Newfoundland. In Major structural zones and faults of the northern Appalachians. Edited by P. St. Julien and J. Belond. Geological Association of Canada, Special Paper 24, pp. 149-173.

Hibbard, J. 1983. Geology of the Baie Verte Peninsula, Newfoundland. Newfoundland Department of Mines and Energy, Memoir $2,280 \mathrm{p}$.

JACOBI, R. and KRISTOFFERSEN, Y. 1981. Transatlantic correlations of geophysical anomalies on Newfoundland, British Isles, France and adjacent continental shelves. In Geology of the north Atlantic borderlands. Edited by J. Wm. Kerr and A.J. Ferguson. Canadian Society of Petroleum Geologists, Memoir 7, pp. 197-230.

JACOBSON, B.H. 1987. A case for upward continuation as a standard separation filter for potential field maps. Geophysics, 52, pp. 11381148.

Jamieson, R.A., Anderson, S., MacDonald, I., and Goodwin, L.B. 1993. Silurian extension along the Humber-Dunnage boundary zone, Baie Verte Peninsula, Newfoundland. Abstracts volume, Late Orogenic extension in mountain belts, Montpellier, France, Document du BRGM no 219.

Keen, C.E., Stockmal, G.S., Welsink, H., Quinlan, G., and Mudford, B. 1987. Deep crustal structure and evolution of the rifted margin northeast of Newfoundland: results from Lithoprobe East. Canadian Journal of Earth Sciences, 24, pp. 1537-1549.

KILFOIL, G.J. and BRUCE, P.A. 1991. Gridded aeromagnetic data, $200 \mathrm{~m}$ grid cell, Newfoundland by 1:250 000 NTS map area. Newfoundland Department of Mines and Energy, Open File NFLD (2063).

Miller, H.G. 1990. A synthesis of the geophysical characteristics of terranes in eastern Canada. Tectonophysics, 177, pp. 171-191.

Miller, H.G. and DeUtSCH, E.R. 1976. New gravitational evidence for the subsurface extent of oceanic crust in north-central Newfoundland. Canadian Journal of Earth Sciences, 13, pp. 459-469.

MiLlER, H.G. and MORRIS, C. 1988. Modelling of gravity and magnetic data along the Lithoprobe lines 84-1 and 84-2, northeast of Newfoundland. Program with Abstracts, Geological Association of Canada Annual Meeting, St. John's, Newfoundland, Volume 13, p. 85.

Quinlan, G.M., Hall, J., Williams, H., Wright, J.A., Colman-Sadd, S.P., O'Brien, S.J., Stockmal, G.S., and Marillier, F. 1992. Lithoprobe onshore reflection transects across the Newfoundland Appalachians. Canadian Journal of Earth Sciences, 29, pp. 18651877.

St. Julian, P., Hubert, C., and Williams, H. 1976. The Baie Verte Brompton line and its possible tectonic significance in the northern Appalachians. Geological Society of America, Program with Abstracts, 8(2), pp. 259-260.

WEAVER, D.F. 1967. A geological interpretation of the Bouguer anomaly field of Newfoundland. Publication of the Dominion Observatory, 35, pp. 223-250.

Williams, H. 1979. Appalachian Orogen in Canada. Canadian Journal of Earth Sciences, 16, pp. 792-807.

Williams, H., Colman-SadD, S.P., and Swinden, H.S. 1988. Tectonicstratigraphic subdivisions of central Newfoundland. In Current Research, Part B, Geological Survey of Canada, Paper 88-1B, pp. 91-98. 
WILLIAMS, H. and HATCHER, R.D. 1982. Suspect terranes and accretionary history of the Appalachian Orogen. Geology, 10, pp. 530-536.

1983. Appalachian suspect terranes. Geological Society of America, Memoir 158, pp. 33-64.

Williams, H. and St. Jullan, P. 1978. The Baie Verte - Brompton Line in Newfoundland and regional correlations in the Canadian Ap- palachians. Geological Survey of Canada, Paper 78-1A, pp. 225229.

Wiseman, R. 1991. A mineralogical and magnetic study of altered ophiolitic ultramafic rocks on the Baie Verte Peninsula, Newfoundland. Unpublished B.Sc. (honours) thesis, Memorial University of Newfoundland, $108 \mathrm{p}$. 